\title{
Musical dynamics in the sensitization of nursing students in the face of palliative care in pediatric oncology ${ }^{a}$
}

\author{
Dinâmica musical na sensibilização dos acadêmicos de enfermagem frente aos cuidados paliativos em \\ oncologia pediátrica
}

\section{Dinámica musical en la sensibilización de los académicos de enfermería frente a los cuidados paliativos en oncología pediátrica}

Cintia Fonseca Nunes ${ }^{1}(1)$

Liliane Faria da Silva ${ }^{1}$

Fátima Helena do Espírito Santo ${ }^{1}$

Fernanda Garcia Bezerra Góes ${ }^{2}$

Juliana Rezende Montenegro Medeiros (10)

de Moraes $^{3}$

1. Universidade Federal Fluminense.

Niterói, RJ, Brasil.

2. Universidade Federal Fluminense.

Rio das Ostras, RJ, Brasil.

3. Universidade Federal do Rio de Janeiro.

Rio de Janeiro, RJ, Brasil.
Corresponding author:

Cintia Fonseca Nunes.

E-mail: cintiafn1@gmail.com

Submitted on 02/05/2018.

Accepted on 07/09/2018.

DOI: 10.1590/2177-9465-EAN-2017-0448

\begin{abstract}
Objective: To analyze the applicability of musical dynamics for nursing students in respect to palliative care in pediatric oncology Methods: A qualitative research using the creative and sensitive method was developed in 2016 in the School of Nursing of a federal university in Rio de Janeiro. 'Musical Body' dynamics was used with ten students in the last year of the graduation course with data being submitted to thematic analysis. Results: The dynamics favored reflection on coping strategies and improving the care provided to children besides reinvigorating the healthcare team. It prompted reflection on empathy, unpreparedness and lack of opportunity to experience pediatric oncology and mourning and was thus an approximation to practical experience. Participants emphasized the possibility of using musical dynamics in the professional setting. Conclusion: Musical dynamics proved to be a useful strategy to sensitize nursing students about palliative care in pediatric oncology.
\end{abstract}

Keywords: Palliative care; Neoplasms; Nursing; Child; Music.

\section{Resumo}

Objetivo: Analisar a aplicabilidade da dinâmica musical na sensibilização de acadêmicos de enfermagem frente aos cuidados paliativos em oncologia pediátrica. Métodos: Pesquisa qualitativa com Método Criativo e Sensível, desenvolvida em 2016, na Escola de Enfermagem de uma Universidade Federal localizada no Rio de Janeiro. Realizada dinâmica corpo-musical com dez acadêmicos do último período da graduação. Dados submetidos à análise temática. Resultados: A dinâmica favoreceu a reflexão sobre estratégias de enfrentamento e melhoria do atendimento à criança, além de revigorar a equipe de saúde. Mobilizou a reflexão sobre empatia, despreparo e falta de oportunidade para vivenciar a oncologia pediátrica e o luto, sendo a mesma uma forma de aproximação com a prática. Levantou-se ainda a possibilidade do seu uso na prática profissional. Conclusão: $\mathrm{A}$ dinâmica musical demonstrou ser uma estratégia adequada para sensibilização dos acadêmicos de enfermagem para cuidados paliativos em oncologia pediátrica.

Palavras-chave: Cuidados Paliativos; Neoplasias; Enfermagem; Criança; Música.

\section{RESUMEN}

Objetivo: Analizar la aplicabilidad de la dinámica musical en la sensibilización de académicos de Enfermería frente a los cuidados paliativos en oncología pediátrica. Métodos: Investigación cualitativa con Método Creador y Sensible, desarrollado en 2016 en la Escuela de Enfermería de una Universidad Federal de Rio de Janeiro. Realizada dinámica cuerpo-musical con diez académicos del último período de la graduación; datos sometidos al análisis temático. Resultados: La dinámica favoreció la reflexión sobre estrategias de enfrentamiento y mejora del servicio al niño, además de revigorizar el equipo de salud. Movilizó la reflexión sobre empatía, falta de preparación y de oportunidad para vivir la oncología pediátrica y el luto, siendo el mismo una forma de acercamiento con la práctica. Los participantes dieron énfasis al uso de la dinámica musical en la práctica profesional. Conclusión: La dinámica musical ha demostrado ser una estrategia apropiada para la sensibilización en los cuidados paliativos en oncología pediátrica.

Palabras clave: Cuidados Paliativos; Neoplasias; Enfermería; Niño; Música. 


\section{INTRODUCTION}

Cancer is characterized by an abnormal behavior of fastgrowing and disordered cells with an ability to invade tissues and organs. These aggressive and uncontrollable cells form malignant tumors that can spread to different regions of the body. ${ }^{1}$

Different to adult cancer for which prevalence is related to dietary factors, lifestyle, alcoholism, smoking and viruses among other causes, pediatric cancer is largely associated with genetic factors and thus creates a feeling of impotence in relation to its prevention. When the diagnosis is early and treatment is started quickly, the chances of disease control and cure are quite significant, at around $70 \% .^{1,2}$

There are several types of cancer treatment; often used in combinations they include surgery, radiation therapy, chemotherapy and bone marrow transplantation. When the possibilities of curative treatment are exhausted and the disease does not regress, palliative care becomes the main approach with every effort being made to make the patient feel comfortable at a time when treatment cannot change the course of the disease. $^{3}$

The World Health Organization (WHO) states that palliative care aims at improving the quality of life of patients with diseases of a life-limiting or life-threatening nature as well as their family members through the prevention and relief of suffering with early identification, adequate evaluation and treatment of pain and other physical, social, psychological and spiritual symptoms. ${ }^{4}$

Such care should be initiated at the time of the diagnosis of the disease in order to accompany therapeutic measures aimed at curing the patient, ${ }^{5}$ as, if a cure cannot be achieved, palliative measures are implemented and continue after the child's death with the offer of support to the family.

The first palliative care service in Brazil appeared in Rio Grande do Sul in 1983, followed by Santa Casa de Misericórdia de São Paulo in 1986 and soon after in Santa Catarina and Paraná. ${ }^{5}$ The National Cancer Institute (INCA) inaugurated Unit IV, which is exclusively dedicated to Palliative Care, in $1998 .{ }^{6}$

Regarding hospital care, one study reported that throughout the treatment of cancer, children and families experience frequent hospitalizations and thus, they become attached to health professionals. This facilitates care actions developed not only at the moment of finitude, but throughout the course of the disease. This can be a source of suffering for health workers who face these situations in the daily care of patients. ${ }^{7}$

The nurse, as a member of the multiprofessional team, is present at the different stages of care and should seek to provide comfort to the child and family throughout treatment until the end of the child's life. This includes helping them to experience the process of dying with dignity, controlling the signs and symptoms, as well as respecting differences, in order to maintain levels of health and quality of life.

However, even today professional training is based on the biomedical model, which seeks healing through technicalscientific knowledge and, due to technological innovation, the health team is increasingly held hostage to this pursuit. In this context, it is reiterated that death is considered to be something undesirable that must be combated..$^{3,8}$

If, on one hand, training is based on the biomedical model with the importance of technology, on the other hand, the nurse, who is the professional who most cares for the patient during the day, ends up facing situations that are not easy to handle. These professionals are not prepared to deal with death, especially in children, due to emotional and personal issues that permeate the situation and by the lack of contact with this issue during their training. . $^{3,8}$

Nursing care requires the professional to have a comprehensive and humanized view with the purpose of caring for patients in their entirety. This is achieved by respecting biopsychosocial and spiritual needs and not just by valuing the execution of specific techniques and practices, ${ }^{5}$ as well as using several means of communication, both verbal and non-verbal, so that the particularities of each person are perceived and understood. ${ }^{9}$

Following this thought, the use of music as a strategy in nursing care has been developing gradually in the Brazilian scenario; it can be used as a tool to bring comfort, reduce pain, facilitate communication and improve the client-professional relationship to health, ${ }^{9}$ reducing the anxiety of patients, thus promoting humanized care. ${ }^{10}$

The success of experiences with music brings to the fore the need to raise awareness of nursing graduates regarding the care they will provide. Thus, the possibility of applying the dynamics of musical creativity and sensitivity is considered a possible tool for learning, research and nurse-patient communication. ${ }^{11}$

In this regard, there are studies that evaluated the perception of family members about the use of music with cancer patients. However, its application in dynamics to sensitize nursing undergraduates to palliative care of children with cancer has not been reported previously. ${ }^{10}$ Hence, this study had the objective of analyzing the applicability of musical dynamics in the sensitization of nursing students regarding palliative care in pediatric oncology.

\section{METHODS}

A qualitative research was developed using the creative and sensitive method based on group discussion, participant observation and artistic production simultaneously taking place within each creativity and sensitivity dynamics. ${ }^{12,13}$

The research was carried out in the School of Nursing of a federal university located in the state of Rio de Janeiro, where the theoretical content of oncology and palliative care in pediatrics is offered in the seventh semester of graduation as a compulsory discipline that addresses the health of hospitalized children. In the curricular matrix, there is also an optional course on oncology, but it does not address pediatrics.

Ten over 18-year-old nursing students participated in this study. The nursing students were chosen from the last semester of the graduation course as in that period they had the disciplines focused on the health of the child and adolescent. Students 
who had temporarily stopped studying the course and those who worked as nursing technicians were excluded since they could have experiences that they had not acquired during the undergraduate course.

For this study, the creativity and sensitivity dynamics, in which one tries to understand the influence of the dynamics mediated by music on the sensitization of participants in respect to a specific theme, was entitled 'Musical Body'.

Based on the creative and sensitive method guidelines, five stages were carried out to develop the dynamics. ${ }^{12,13}$ The first involved the organization of the venue and the reception of the participants. Soon after the room was re-arranged so that the participants could see each other but with space between them. They were given silhouettes of human bodies drawn on $20 \times 21$ $\mathrm{cm}$ sheets of brown paper as well as colored adhesive paper (green, yellow and pink) to use during each piece of music that would be played.

In the second stage, the operationalization of the dynamics was explained, the debate-generating question was presented, orally and in writing, and the artistic productions were elaborated. At this time, a breathing exercise for relaxation was also proposed during a two-minute piece of music with the sounds of rain and nature. Each participant was asked to take three deep breaths so that they were prepared to listen to the music.

Subsequently, the following story was told to inform each participant of the imaginary problem situation. "You are a pediatric oncology nurse and you arrive for your 12-hour shift. On handing over the shift, the night shift nurse says that Pedro (fictitious name), a patient, did not sleep well last night, he felt much pain, discomfort and always asked her to help him stop feeling the pain. Furthermore, as he knew he was going to die he wanted to go quickly so he would not feel it any more. Pedro is nine years old, his diagnosis, acute lymphocytic leukemia, was discovered when he was three years old and he was treated until age five when he got better. He relapsed at age seven, was submitted to the appropriate curative treatments but without success and today he is hospitalized for palliative care. His mother, who is his caregiver, said that he always coped well with the disease, liked playing with his seven-year-old brother and playing ball. He misses his older brother because they had not seen each other for some time. You go to the patient's room and his mother is asleep. Pedro is awake but rather sleepy due to medications. He asks you to come close and then makes a request: 'I know I'm going to die, I tried, but now I cannot. Please help me!'You need to deal with this situation and offer the care Pedro deserves for his comfort."

At this moment, the debate-generating question was exposed to elaborate their artistic productions: in what way can musical dynamics sensitize the nursing student to palliative care in pediatric oncology?

Then, during each piece of music, the participants wrote what they felt on the adhesive paper (green, yellow and pink) according to the order of the music and the paper was adhered to the silhouette of the body placed in the file at the beginning of the dynamics. Three pieces of music of different styles were played: Canon (Pachelbel) - classical; Somewhere Over the Rainbow (Israel Kamakawiwo'Ole) - Surf music; Sweet Child O' Mine (Guns N' Roses) - rock, respectively. The pieces of music were chosen based on articles that reported diverse musical styles from which the music was matched with the target audience of the research.

Subsequently, in the third stage, after listening to the three pieces of music, the artistic production of each participant was presented beginning with a description about what they had written, felt and represented. Thus, the individually produced material was presented to the group and the researcher recorded the convergent and divergent impressions from which the generating themes were codified. The fourth stage involved analysis and group discussion and the fifth stage summarized emerging themes and sub-themes with ensuing validation by the participants themselves.

For the operationalization of the dynamics, in addition to the researcher who acted as the coordinator of the group, there is a need for a research assistant to observe and register the behaviors of the participants, as well as to control the audio recorder. ${ }^{12,13}$ This was performed by a graduate student who had learnt the step-by-step dynamics used.

It is noteworthy that all the invited students accepted to participate in the dynamics as research volunteers and no one withdrew. After transcription and data analysis, there was no need for further recruitment, as the criterion of concluding data collection was theoretical saturation. ${ }^{14}$

The duration of the creativity and sensitivity dynamics was 44 minutes. It was recorded on an electronic voice recorder and the dialogues were transcribed in full and analyzed according to the three phases of the thematic analysis:

1. Pre-analysis: the analyst's approach to the empirical material produced in the dynamics through floating readings;

2. Exploration phase: in which the formation of thematic units was sought by aggregating textual fragments and sentences that had similar meaning;

3. Treatment phase and the interpretation of the results and their basis based on the best scientific evidence about the issue..$^{15}$

This research was approved by the Research Ethics Committee of the institution (CAAE: 59605916.8.0000.5243 - Report \# 1.786.838, 10/20/2016 2). In compliance with the norms of Resolution 466 of the National Health Council dated December 12, 2012, the participants signed two copies of the informed consent form; one copy stayed with the researcher and the other with the participant. The student nurses were ensured anonymity by using alphanumeric identification codes. All the data will be stored by the researcher for five years and then destroyed. 


\section{RESULTS}

Ten nursing students, two men and eight women, aged between 21 and 27 years from a group of 30 students from the last semester of the nursing graduation course participated in the study.

The following thematic units emerged based on the analysis of the answers of the students: musical dynamics stimulating palliative care strategies in pediatric oncology and sensitization of students to palliative care in pediatric oncology.

\section{Musical dynamics stimulating palliative care strategies in pediatric oncology}

The musical dynamics aroused the fear of being in the situation of a nurse in the students' thoughts, but also led them to think of strategies to face the fact, such as the use of alternative therapy, visit of the brother, and to talk to the child and his family.

So, thinking about a 9-year-old in this situation, it scares me, it frightens me. But at the same time it gave me a little courage, that I need to do something to face it (SN 1).

I think it would help me try to do something better for him, even with palliative care, he needs attention, try to do some alternative therapy beyond pharmacological to try to improve the pain issue. Maybe bring his brother, once in a while for a visit, or even get in touch with the rest of the team to see the possibility of him maybe going home (SN 2).

Trying to make his passage a little less bad, less painful. (...) And also to start talking to the family. About what is going to happen and how his passing might be, his leaving. Start working with this in the heads of family members or at least see what the relative wants (SN 3).

I began to think that I would talk to this patient, try to listen to him in the best way possible, see what he wants. (SN 8).

The proposal also helped to develop feelings of hope and the reflection that healing will not always happen, but that things can be improved, and a way to make this happen would be the presence of the nurse next to the child and the family.

I think I'm calm, both as a nurse and as a person, I'm going to be able to take better care of this child, to be there at his side at this difficult time, and the relatives too. I also included in the artistic production hope, I believe it did not end there, that if the person believes he can go to a better place and it was just a passage that he had to do, but that what lies ahead is very quiet, very beautiful, cheerful (SN 4).

I thought more or less like SN 4, like the hope, because we think, maybe a child dying, we'll do something to get him out of it, but sometimes healing will not always happen, so we have to think in this way, it can improve, but not necessarily with a cure (SN 5).

\section{Musical dynamics in the sensitization of students to palliative care in pediatric oncology}

Nursing students emphasized the importance of musical dynamics in the care practice, considering that, with routine and many years of the profession, there may be a loss of sensitivity to palliative care, and such a strategy would contribute to a return of better quality of care, to dedication to care, as well as invigorating the health team.

With practice, these situations begin to be more routine and many people are losing some of the sensitivity. Such a dynamic would make you think about these cases, think and not let it get lost like this, with years of profession (...). It is essential for nursing staff to maintain quality of care (SN 1).

Palliative care is a very hard thing. And it does not look like it, but this [dynamic] here is essential for a team that is worn out, long time there, do you understand? (SN 6)

I think that a dynamic like this would help in the professional life, because the music affects our emotions, then, sometimes we put some music on to feel better, to have more courage (SN 7).

The musical dynamics raised the discussion of the need for the health professional to have empathy, that is, to put themselves in the place of the other, and it is an important tool to facilitate comprehensiveness, since they said that the disciplines at college are fragmented without moments of reflection about palliative care in pediatric oncology.

Every healthcare professional needs to work with empathy, when we listen to these pieces of music we put ourselves in the patient's shoes, so that's what we'll take when we've graduated (SN 4).

During graduation, we have three separate subjects. A discipline that talks about death, that is, applied psychology for health, a discipline about children and a discipline about therapies, but there is nothing that integrates all this (...). I think that this moment of reflection that the dynamics provided is lacking (SN 9).

Students raised the issue of unpreparedness and lack of opportunity to experience pediatric oncology and bereavement with musical dynamics being a way of reflection and bringing this practice close.

I do not think we're ready. I want to save lives (SN 7).

We have no contact with pediatric oncology, but I believe that everyone should take a little bit of what people felt today. (...) Nobody is prepared for mourning, never will be, but a dynamic or group discussion helps to get us a little better prepared (SN 4). 
We are only prepared for that when we experience it, because here we are not (...) and here in college we will never see it, because the hospital that we study in does not have that opportunity, do you understand? So feel, be here and feel, even if it is not so real, but a little, I think it will help a lot (SN 6).

So, in practice, everything is different, and these reflections that happened here (dynamics) if they were done more often it is essential for Us (SN 1).

Participants reported that they would use the dynamics presented to relax and calm down, as well as to facilitate thinking about therapeutic possibilities. They showed they were willing to use the dynamics when they are nurses with the health team of a sector.

I as a nurse, a team leader, I would even think about using this dynamics, put music on, relax and then think about the therapeutic possibilities. In any situation, any sector, if I could, every day I would start my shift with my team playing a piece of music, everyone relax, at the start and end of the shift, I would use this dynamics (SN 10).

And I think, I as a nurse, I would be calm, it would be more to relax, It would not lead me to any such thinking (SN 7).

\section{DISCUSSION}

The results of this research showed that musical dynamics could be used as a technology to sensitize nurses/students and to arouse creative aspects related to the palliative care of children with cancer. Music is thus a powerful channel of communication, expression of suffering and helps in coping with the patients' last moments of life. ${ }^{16,17}$

Palliative care encompasses multidisciplinary care aimed at offering the best quality of life for patients and their families. This can be improved by improving the family/child relationship and creating more welcoming environments; ${ }^{18}$ these strategies were cited by the students participating in this study.

One strategy that was considered by the students and that is in cohesion with the literature was the valorization of the dialogue with the child and the family while being attentive to their needs. For this, sensitive listening is necessary, and listening to the other is something that requires training, even beyond assistential situations. ${ }^{19}$

The dialogues of the participants are in line with findings in the literature that highlight the value of staff and parents as a source of trust, spiritual support and solidarity for the child in palliative care in order to create an environment that promotes quality of life. ${ }^{18}$

One study reported the need for the health professional to prioritize his or her assistance to meet the needs of the patient without resulting to care solely focused on the physical dimension, to be attentive to the integrality that makes up a human being always. It is therefore a question of shifting the focus of disease cure and performing procedures to care that provides restoration. ${ }^{19}$

The students stated that musical dynamics could be a strategy adopted in care as a way to invigorate the team, which is sometimes worn out due to the work. The study points out that because of this weariness, many professionals leave the service or they perform the work mechanically, repetitively and routinely in order to escape their feelings or due to excess workload. This can lead to loss or reduction in the ability to produce, thus negatively influencing the quality of care provided. ${ }^{20}$

The participants of the study described benefits that are in agreement with the literature, in which the gains of musical dynamics as perceived by the students range from prevention of psychological stress to greater commitment to professional activities and social integration. ${ }^{11}$

With the benefits mentioned, the healthcare team can feel invigorated and provide quality care with dedication to their patients. An integrative review study emphasized that nursing can be considered the care environment itself, not just part of it, thus it is necessary to focus on it, assuming that the nurse's attitude toward the patient can make a difference. ${ }^{16}$

Another study confirmed that nursing is able to access the emotional and subjective aspects through communication and empathy. However, for the development of empathic behavior, it is necessary to be willing to worry about the behavior of others, and thus it is a conscious act, aiming at improving interpersonal relationships through affective bonding and communication skills, ${ }^{19}$ which requires professional training beyond the biological aspects and the disease.

Corroborating with the participants' statements on the fragmentation of existing subjects on the curriculum, an article described the need to take courses on palliative care presented longitudinally throughout the training process thereby strengthening the notion that healing and palliative care go hand in hand. ${ }^{21}$ In addition, it is necessary to motivate students in respect to this problem, which generates deep meanings in their education and professional actions. Using this logic, another study also emphasized the importance of palliative care specifically in pediatric oncology, considering that this is the first step in raising awareness and preparing the future professional. ${ }^{3}$

Another study portrayed the importance of palliative care in the training of health professionals, demonstrating that the students who experienced end-of-life care of a patient could work through a complex of impressions, feelings and exchanges that are not possible with the theory alone. This transforms practical activities into a real laboratory of creation of individual and shared knowledge, complementing the theoretical education. ${ }^{21}$

It is necessary to use strategies, to try to minimize the lack of opportunity experienced by the students and to bring them closer to the reality of palliative care in pediatric oncology. An article evidenced the quality of musical dynamics in relation to the promotion of self-knowledge, reflection and perception of 
the other, indispensable elements for personal development and social integration; ${ }^{22}$ this corroborates the findings of the present study.

Concerning the stimulus of thought for possibilities of therapeutic actions as cited by the participants, this study on musical dynamics agreed with published works, in which teaching music influences the attention, memory, development of logical thinking, creativity, the intellectual maturation, the perception, ${ }^{23}$ the expression of emotions and rationality, thus facilitating the development of learning abilities and thought processes. ${ }^{16}$

Studies have also pointed out, in agreement with the participants of the present study, that the difficulty in the management of children in palliative care has as one of the main justifications the lack of teaching and training to deal with aspects that involve the end of life, such as bioethical foundations, and communication and assistance strategies. This unpreparedness over time and with the complexity of the moment of loss associated with postural or behavioral slipups may result in unimaginable consequences, often leaving persistent marks in this family. ${ }^{3,18}$

Therefore, health professionals working with palliative care in pediatrics need to have a comprehensive training so that they can understand that this type of care is not the opposite of curative therapy, and that it is necessary to integrate the two models to promote the quality of life of the children and their families. Among their actions are the recognition and management of the symptoms presented by the children, the ability to work in a team, maintaining a good relationship with family and child and discussion of issues related to the end of life. ${ }^{24}$

Finally, the nurse's role with the child with cancer in palliative care should be permeated by attitudes that promote comfort and physical, emotional and spiritual well-being of the children and their families. ${ }^{25}$ Therefore, the instrumentalisation of nursing students for palliative care in pediatric oncology cannot be restricted to the teaching of technical care. It is necessary to go beyond this by using strategies such as musical dynamics that encompass the subjective aspects that this care involves.

\section{CONCLUSION}

Musical dynamics has proven to be an adequate strategy for raising the awareness of nursing students for palliative care in pediatric oncology. Participants were able to feel affinity in respect to the proposed history and reflect on the professional stress caused by the years of the profession and the lack of opportunity to learn the subject during graduation.

The need for a reformulation of the curriculum to cover the topic of oncology longitudinally throughout the course was one of the points discussed by the participants. In addition, the importance of empathy in care as a way to win the trust of the child and family for the environment to become harmonious was emphasized as well as coping strategies to deal with the situation experienced by the child.
As a contribution to nursing and aimed at the specific public of pediatric oncology, this study provided a means of understanding the subject of palliative care more deeply. In addition, it highlights flaws in the curriculum of the nursing professional. Thus, it is expected that new teaching strategies could be developed to fill existing gaps in the training process of future nurses.

A limitation of this research is the scarcity of publications highlighting strategies to teach palliative care of children during the nurses' training course in order to compare this study with others.

\section{REFERENCES}

1. Ministério da Saúde (BR). Instituto Nacional do Câncer José Alencar Gomes da Silva (INCA). O que é Câncer. [Internet]. 2016; [cited 2017 Jul]. Available from: http://www2.inca.gov.br/wps/wcm/connect/cancer/ site/oquee

2. Ministério da Saúde (BR). Instituto Nacional do Câncer José Alencar Gomes da Silva (INCA). Estimativa: 2014 - Incidência de Câncer no Brasil. Rio de Janeiro: INCA; 2014. [Internet]. [cited 2017 Jul]. Available from: http://www.saude.sp.gov.br/resources/ses/perfil/ gestor/homepage/outros-destaques/estimativa-de-incidencia-decancer-2014/estimativa_cancer_24042014.pdf

3. Guimarães TM, Silva LF, Santo FHE, Moraes JRMM. Cuidados paliativos em oncologia pediátrica na percepção dos acadêmicos de enfermagem. Esc Anna Nery [Internet]. 2016; [cited 2017 Jul]; 20(2):261-7. Available from: http://www.scielo.br/pdf/ean/v20n2/1414 8145-ean-20-02-0261.pdf

4. World Health Organization (WHO). National cancer control programs. Policies and managerial guidelines. 2nd ed. Geneva: World Health Organization; 2002. [Internet]. [cited 2018 Apr]. Available from: http:// bit.ly/1UbsrZq

5. Silva MM, Santanda NGM, Santos MC, Cirilo JD, Barrocas DLR, Moreira MC. Cuidados paliativos na assistência de alta complexidade em oncologia: percepção de enfermeiros. Esc Anna Nery [Internet] 2015; [cited 2017 Feb]; 19(3):460-6. Available from: http://www.scielo. br/pdf/ean/v19n3/1414-8145-ean-19-03-0460.pdf

6. Hermes HR, Lamarca ICA. Cuidados paliativos: uma abordagem a partir das categorias profissionais de saúde. Ciênc Saúde Coletiva [Internet].2013; [cited 2017 Dec]; 18(9):2577-88. Available from: http:// www.redalyc.org/pdf/630/63028227012.pdf

7. Silva AF, Issi HB, Motta MGC, Botene DZA. Cuidados paliativos em oncologia pediátrica: percepções, saberes e práticas na perspectiva da equipe multiprofissional. Rev Gaúcha Enferm [Internet]. 2015 Jul; [cited 2017 Feb]; 36(2):56-62. Available from: http://www.scielo.br/pdf/ rgenf/v36n2/pt_1983-1447-rgenf-36-02-00056.pdf

8. Picanço CM, Sadigursky D. Concepções de enfermeiras sobre o prolongamento artificial da vida. Rev Enferm UERJ [Internet]. 2014 Sep/Oct; [cited 2017 Nov]; 22(5):668-73. Available from: http://www. facenf.uerj.br/v22n5/v22n5a14.pdf

9. Sales CA, Silva VA, Pilger C, Marcon SS. A música na terminalidade humana: concepções dos familiares. Rev Esc Enferm USP [Internet] 2011; [cited 2018 Jun]; 45(1):138-45. Available from: http://www.scielo. br/pdf/reeusp/v45n1/19.pdf

10. Silva VA, Marcon SS, Sales CA. Percepções de Familiares de pessoas portadoras de câncer sobre encontros musicais durante o tratamento antineoplásico. Rev Bras Enferm [Internet]. 2014 May/Jun; [cited 2017 Feb]; 67(3):408-14. Available from: http://www.scielo.br/scielo. php?script=sci_arttext\&pid=S0034-71672014000300408

11. Bergold LB, Alvim NAT, Cabral IE. O lugar da música no espaço do cuidado terapêutico: sensibilizando enfermeiros com a dinâmica musical. Texto Contexto Enferm [Internet]. 2006 Apr/Jun; [cited 2017 Jul]; 15(2):262-9. Available from: http://www.scielo.br/pdf/tce/v15n2/ a09v15n2.pdf 
12. Silva LF, Cabral IE. O resgate do prazer de brincar da criança com câncer no espaço hospitalar. Rev Bras Enferm [Internet]. 2015; [cited 2018 Jun]; 68(3):337-42. Available from: http://www.scielo.br/pdf/reben/ v68n3/0034-7167-reben-68-03-0391.pdf

13. Silva LN, Silva LF, Goes FGB, Machado MED, Paiva ED. Orientações sobre quimioterapia junto à criança com câncer: método criativo sensível. Braz J Nurs [Internet]. 2015; [cited 2018 Apr]; 14(Suppl. 4):47180. Available from: http://www.objnursing.uff.br/index.php/nursing/ article/view/5310

14. Fontanella BJB, Luchesi BM, Saidel MGB, Ricas J, Turato ER, Melo DM. Sampling in qualitative research: a proposal for procedures to detect theoretical saturation. Cad Saúde Pública [Internet]. 2011 Feb; [cited 2018 Apr]; 27(2):389-94. Available from: http://www.scielosp.org/pdf/ csp/v27n2/20.pdf

15. Minayo MCS. O desafio do conhecimento: pesquisa qualitativa em saúde. $13^{\mathrm{a}}$ ed. São Paulo: Hucitec; 2013.

16. Barcelos VM, Teixeira ER, Ribeiro ABN, Silva LDB, Rodrigues DP, Siqueira ASA. Music therapy in patients with mental disorders. J Nurs UFPE On Line [Internet]. 2018 Apr; [cited 2018 Apr]; 12(4):1054-9. Available from: https://periodicos.ufpe.br/revistas/revistaenfermagem/ article/view/231436/28675

17. Bergold LB, Alvim NAT. Influência dos encontros musicais no processo terapêutico de sistemas familiares na quimioterapia. Texto Contexto Enferm [Internet]. 2011; [cited 2017 Feb]; 20(Esp):108-16. Available from: $h$ ttp://www.scielo.br/pdf/tce/v20nspe/v20nspea14.pdf

18. Guimarães TM, Silva LF, Santo FHE, Moraes JRMM, Pacheco STA. Cuidado paliativo em oncologia pediátrica na formação do enfermeiro. Rev Gaúcha Enferm [Internet]. 2017 Mar; [cited 2018 Apr]; 38(1):e65409. Available from: http://www.scielo.br/pdf/rgenf/v38n1/0102-6933rgenf-1983-144720170165409.pdf
19. Savieto RM, Leão ER. Assistência em Enfermagem e Jean Watson: Uma reflexão sobre a empatia. Esc Anna Nery [Internet]. 2016; [cited 2017 Dec];20(1):198-202. Available from: http://www.scielo.br/pdf/ean/ v20n1/1414-8145-ean-20-01-0198.pdf

20. Santana LL, Miranda FMDA, Karino ME, Baptista PCP, Felli VEA, Sarquis LMM. Cargas e desgastes de trabalho vivenciados entre trabalhadores de saúde em um hospital de ensino. Rev Gaúcha Enferm [Internet] 2013; [cited 2017 Nov]; 34(1):64-70. Available from: http://www.scielo. $\mathrm{br} / \mathrm{pdf} / \mathrm{rgenf} / \mathrm{v34n1/08.pdf}$

21. Costa AP, Poles K, Silva AE. Formação em cuidados paliativos experiência de alunos de medicina e enfermagem. Interface (Botucatu) [Internet]. 2016; [cited 2017 Nov]; 20(59):1041-52. Available from: http:// www.scielo.br/pdf/icse/v20n59/1807-5762-icse-1807-576220150774.pdf

22. Zanettini A, Souza JB, Franceschi VE, Finger D, Gomes A, Santos MS Quem canta seus males espanta: um relato de experiência sobre o uso da música como ferramenta de atuação na promoção da saúde da criança. Rev Min Enferm [Internet]. 2015 Oct/Dec; [cited 2018 Jun]; 19(4):1060-4 Available from: http://www.reme.org.br/artigo/detalhes/1058

23. Bergold LB, Alvim NAT. A música terapêutica como uma tecnologia aplicada ao cuidado e ao ensino de enfermagem. Esc Anna Nery [Internet]. $2009 \mathrm{Jul} / \mathrm{Sep}$; [cited $2018 \mathrm{Jul}$ ]; 13(3):537-42. Available from: http://www.scielo.br/pdf/ean/v13n3/v13n3a12.pdf

24. Valadares MTM, Mota JAC, Oliveira BM. Cuidados paliativos em pediatria: uma revisão. Rev Bioét [Internet]. 2013 Sep/Dec; [cited 2018 Apr]; 21(3):486-93. Available from: http://www.scielo.br/scielo. php?script=sci_arttext\&pid=S1983-80422013000300013\&lng=en

25. Monteiro ACM, Rodrigues BMRD, Pacheco STA, Pimenta LS. A atuação do enfermeiro junto à criança com câncer: cuidados paliativos. Rev Enferm UERJ [Internet]. 2014 Nov/Dec; [cited 2018 Apr]; 22(6):77883. Available from: http://www.e-publicacoes.uerj.br/index.php/ enfermagemuerj/article/view/15665/12267

\footnotetext{
${ }^{a}$ Article extracted from the final study of undergraduate nursing bachelor degree, named "Musical dynamics to sensitize nursing students about palliative care in pediatric oncology" carried out in the Center for Research and Studies on Integral Health of Children and Adolescents. Universidade Federal Fluminense. 2017. The study was authored by the first author under supervisor of the second author.
} 